\title{
Tin Protoporphyrin Inhibits Carbon Monoxide Production in Adult Mice
}

\author{
GREGORY S. MILLEVILLE, MICHAEL D. LEVITT, AND ROLF R. ENGEL \\ Departments of Pediatrics and Internal Medicine, Hennepin County Medical Center, Research Service, Veteran's \\ Administration Medical Center, and the University of Minnesota School of Medicine, \\ Minneapolis, Minnesota 55415
}

\begin{abstract}
We studied the effect of tin protoporphyrin, a potent inhibitor of heme oxygenase (EC 1.14.99.3), on carbon monoxide $(\mathrm{CO})$ production in mature mice. Measurements of $\mathrm{CO}$ production provide a sensitive, noninvasive means of quantitating heme catabolism. $\mathrm{CO}$ accumulation in the gas space of closed chambers was decreased by about $25 \%$ for mice treated with two $50 \mathrm{nmol} / \mathrm{g}$ doses of tin protoporphyrin as compared to saline-treated controls. Calculated rates of $\mathrm{CO}$ production were $0.28 \pm 0.07$ and 0.40 $\pm 0.05 \mathrm{nmol} \cdot \mathrm{g}^{-1} \cdot \mathrm{h}^{-1}$ for mice injected with tin protoporphyrin and saline, respectively $(p<0.01)$. When hemin $(125 \mathrm{nmol} / \mathrm{g})$ was administered to simulate hemolysis, $\mathrm{CO}$ production increased markedly in both saline- and tin protoporphyrin-treated mice. However, the rate of $\mathrm{CO}$ production in tin protoporphyrin-treated mice was only $44 \%$ that of saline-treated animals $(p<0.0001)$. These studies demonstrate that tin protoporphyrin inhibits heme catabolism in both the basal- and heme-loaded states and confirm that this inhibition is at the heme oxygenase step in the heme to bilirubin pathway. (Pediatr Res 19: 94-96, 1985)
\end{abstract}

\section{Abbreviation}

CO, carbon monoxide

Heme oxygenase (EC 1.14.99.3) catalyzes the equimolar formation of $\mathrm{CO}$ and biliverdin from heme, which is the first step in the conversion of heme to bilirubin (17). Since CO production results solely from heme catabolism, $\mathrm{CO}$ production quantitatively reflects the rate of heme catabolism and parallels bile pigment production (3).

Recently, Drummond and Kappas (6) reported that administration of tin protoporphyrin to newborn rats prevented the rise in heme oxygenase activity and serum bilirubin concentration which normally occurs during the neonatal period. In the present report we utilized measurements of $\mathrm{CO}$ production to quantitate the influence of tin protoporphyrin on heme catabolism in adult mice.

\section{MATERIALS AND METHODS}

Materials. Tin protoporphyrin was obtained from Porphyrin Products (Logan, UT). Hemin (bovine) was purchased from

Received March 12, 1984; accepted August 8, 1984.

Requests for reprints should be addressed to Dr. Rolf Engel, Neonatal ICU-862, Hennepin County Medical Center, 701 Park Avenue South, Minneapolis, MN 55415 .

Reported in abstract form in Pediatr Res 17:239A (1983).
Sigma (St. Louis, MO). Each of these components was dissolved in $0.5 \% \mathrm{NaHCO}_{3}$ solution. Swiss-White mice were obtained from Bio-Lab Corp (St. Paul, MN). Soda lime (Sodasorb) was obtained from W. R. Grace \& Co. (Lexington, MA).

Gas assays. Gas samples were analyzed by gas chromatography for $\mathrm{O}_{2}$ with a thermal conductivity detector (Beckman, Palo Alto, $\mathrm{CA}$ ) and for $\mathrm{CO}$ with a reduction detector (Trace Analytical, Menlo Park, CA) in series. Samples were injected via gas sample valves into a $3 \mathrm{ft}$ by $1 / 8$ inch diameter stainless steel column packed with molecular sieve $5 \mathrm{~A}$. Column temperature was maintained at $100^{\circ} \mathrm{C}$ and highly purified argon was used as a carrier gas at a flow rate of $40 \mathrm{ml} / \mathrm{min}$.

Experimental procedure. Swiss-White mice aged 6-8 wk were randomly assigned to receive tin protoporphyrin or normal saline. The treated animals received $50 \mathrm{nmol} / \mathrm{g}$ of tin protoporphyrin via intraperitoneal injection while controls received an equal volume of normal saline. The mice were then placed on a liquid diet of 5\% glucose and electrolytes (Pedialyte, Ross Labs., Columbus, $\mathrm{OH}$ ) for the duration of the experiment, as previous studies had demonstrated that mice fed commercial rodent food produced increased amounts of $\mathrm{CO}$ which did not reflect endogenous heme degradation (10). In addition, a pilot study for the present series demonstrated that three mice fed infant formula produced appreciably more $\mathrm{CO}$ than that expected from a theoretical calculation of endogenous heme turnover in the mouse as well as greater $\mathrm{CO}$ than that subsequently observed with Pedialyte feedings. Eighteen hours after the first injection, the same dose of tin protoporphyrin or saline was readministered and the animals were placed in individual glass chambers as previously described (9). Briefly, each mouse was placed in an airtight chamber which had a volume of $680 \mathrm{ml}$. Soda lime in the chambers absorbed $\mathrm{CO}_{2}$. A one-way valve allowed $\mathrm{O}_{2}$ to enter each chamber to replace that consumed by the animal. An initial gas sample was taken after a 4-h period of equilibration and a final sample was obtained $18 \mathrm{~h}$ later. Oxygen and $\mathrm{CO}$ concentrations were measured in each sample.

A second series of experiments was performed which was similar to that described above with the exception that each animal was also given an intraperitoneal injection of hemin (125 $\mathrm{nmol} / \mathrm{g}$ ) just prior to placement in the chamber.

Calculations. The moles of $\mathrm{CO}$ accumulated in the gas space for each animal over an 18-h interval was determined after correcting for ambient temperature. The rate of $\mathrm{CO}$ production was calculated from the change in gas space $\mathrm{CO}$ content and $\mathrm{CO}$ stores in the mouse with correction for $\mathrm{CO}$ removed during gas sampling and $\mathrm{CO}$ added via trace contamination of the $\mathrm{O}_{2}$ supply. CO catabolism was presumed to be negligible (12) and, therefore, was not included in the calculated rate of production. Total mouse $\mathrm{CO}$ stores were calculated assuming a blood volume of $5.5 \mathrm{ml} / 100 \mathrm{~g}, \mathrm{Hb}$ concentration of $13.5 \mathrm{~g} / \mathrm{dl}(15)$, extravascular $\mathrm{CO}$ stores of $20 \%$ of total body CO content (12), and $\mathrm{COHb}$ as 
Table 1. Increase of $C O$ content of chamber gas space

\begin{tabular}{lcccc}
\hline \multicolumn{1}{c}{ Group } & $\begin{array}{c}\text { Normal } \\
\text { saline }\end{array}$ & $\begin{array}{c}\text { Tin } \\
\text { protoporphryin }\end{array}$ & $\begin{array}{c}\text { Normal saline } \\
\text { + hemin }\end{array}$ & $\begin{array}{c}\text { Tin protoporphyrin } \\
+ \text { hemin }\end{array}$ \\
\hline No. of mice & 6 & 6 & 14 & 13 \\
Wt $(\mathrm{g})$ & $24.1 \pm 2.7$ & $25.3 \pm 3.4$ & $28.5 \pm 6.7$ & $26.5 \pm 5.1$ \\
$\begin{array}{l}\text { Net CO increase in gas space } \\
\text { over 18 } \mathrm{h}(\mathrm{ppm})\end{array}$ & $5.9 \pm 0.9$ & $4.6 \pm 1.1^{*}$ & $32.4 \pm 9.8$ & $14.3 \pm 4.2^{* * *}$ \\
$\begin{array}{l}\text { Rate of CO increase in gas } \\
\text { space }\left(\mathrm{nmol} \cdot \mathrm{g}^{-1} \cdot \mathrm{h}^{-1}\right)\end{array}$ & $0.38 \pm 0.03$ & $0.29 \pm 0.05^{* *}$ & $1.80 \pm 0.43$ & $0.85 \pm 0.17^{* * *}$ \\
\hline
\end{tabular}

All data given mean $\pm 1 \mathrm{SD}$.

${ }^{*} p<0.05,{ }^{* *} p<0.01$ compared to normal saline group, ${ }^{* * *} p<0.0001$ compared to normal saline + hemin group.

calculated below by the Haldane equation (5):

$$
\mathrm{K}=\frac{\mathrm{COHb}}{\mathrm{O}_{2} \mathrm{Hb}} \cdot \frac{\mathrm{PAO}_{2}}{\mathrm{PACO}}
$$

where $\mathrm{K}$ is the relative affinity constant of $\mathrm{Hb}$ for $\mathrm{CO}$ and $\mathrm{O}_{2}$, and $\mathrm{COHb}$ and $\mathrm{O}_{2} \mathrm{Hb}$ are the fractions of $\mathrm{Hb}$ saturated with $\mathrm{CO}$ and $\mathrm{O}_{2}$, respectively. Under the conditions of the experiment, $\mathrm{O}_{2} \mathrm{Hb}$ may be expressed as $1-\mathrm{COHb}$. $\mathrm{K}$ for mouse $\mathrm{Hb}$ is approximately 148 (5). Alveolar $\mathrm{O}_{2}$ concentration was assumed to be 45 torr less than inspired $\mathrm{O}_{2}$ and alveolar $\mathrm{CO}$ concentration was assumed to equal measured $\mathrm{CO}$ concentration in the chamber gas space. A trace amount of $\mathrm{CO}$ was present in the oxygen supply $(1.4 \mathrm{ppm})$ : correction for this amount was calculated using the reported average oxygen consumption rate of $1.59 \mathrm{ml} /$ $\mathrm{g} / \mathrm{h}(13)$.

The data are presented as $\pm 1 \mathrm{SD}$. Statistical significance was determined by the unpaired $t$ test.

\section{RESULTS}

$\mathrm{CO}$ accumulation in the gas space was significantly decreased $(p<0.05)$ for mice that had been injected with tin protoporphyrin (Table 1). For mice receiving saline injections, $\mathrm{CO}$ accumulated at a rate of $0.38 \mathrm{nmol} \cdot \mathrm{g}^{-1} \cdot \mathrm{h}^{-1}$ in the chamber gas space. In contrast, for mice injected with tin protoporphyrin, the average rate of $\mathrm{CO}$ accumulation in the chamber gas space was $24 \%$ less, or $0.29 \mathrm{nmol} \cdot \mathrm{g}^{-1} \cdot \mathrm{h}^{-1}$.

A slightly greater difference between control and tin protoporphyrin-treated animals was observed when the rate of $\mathrm{CO}$ production was calculated. The calculated rate of $\mathrm{CO}$ production for control mice was $0.40 \mathrm{nmol} \cdot \mathrm{g}^{-1} \cdot \mathrm{h}^{-1}$ versus $0.28 \mathrm{nmol} \cdot \mathrm{g}^{-1}$. $\mathrm{h}^{-1}$ for mice treated with tin protoporphyrin $(p<0.01)$ (Fig. 1$)$.

The injection of hemin $(125 \mathrm{nmol} / \mathrm{g})$ increased the rate of CO accumulation in the chamber gas space to $1.80 \mathrm{nmol} \cdot \mathrm{g}^{-1} \cdot \mathrm{h}^{-1}$ as opposed to the mean rate of $0.38 \mathrm{nmol} \cdot \mathrm{g}^{-1} \cdot \mathrm{h}^{-1}$ for the nonheme injected control mice (Table 1) $(p<0.0001)$. The effect of hemin injections on calculated $\mathrm{CO}$ production was equally pronounced with a rise from $0.40 \mathrm{nmol} \cdot \mathrm{g}^{-1} \cdot \mathrm{h}^{-1}$ for control mice to 2.38 $\mathrm{nmol} \cdot \mathrm{g}^{-1} \cdot \mathrm{h}^{-1}$ after hemin injection.

The rate of $\mathrm{CO}$ accumulation in the gas space for heminloaded mice was decreased from $1.80 \mathrm{nmol} \cdot \mathrm{g}^{-1} \cdot \mathrm{h}^{-1}$ for salinetreated mice to $0.85 \mathrm{nmol} \cdot \mathrm{g}^{-1} \cdot \mathrm{h}^{-1}$ for tin protoporphyrin-injected mice $(p<0.0001)$ (Table 1). The calculated rate of $\mathrm{CO}$ production was depressed by about $56 \%$ with controls producing $2.38 \mathrm{nmol} \cdot \mathrm{g}^{-1} \cdot \mathrm{h}^{-1}$ and tin protoporphyrin-treated mice producing $1.05 \mathrm{nmol} \cdot \mathrm{g}^{-1} \cdot \mathrm{h}^{-1}(p<0.001)$ (Fig. 2). Tin protoporphyrin decreased the fraction of exogenous heme that was catabolized to $\mathrm{CO}$ from 28 to $11 \%$ during the $18 \mathrm{~h}$ of the experiment.

\section{DISCUSSION}

Tin protoporphyrin is an inhibitor of heme oxidation in vitro and in vivo $(6-8,11)$ Drummond and Kappas (6) reported that a single injection of this synthetic metalloporphyrin prevented the rise of serum bilirubin normally observed in neonatal rats.

In contrast to serum bilirubin concentrations which reflect the balance between heme breakdown and bilirubin excretion, $\mathrm{CO}$

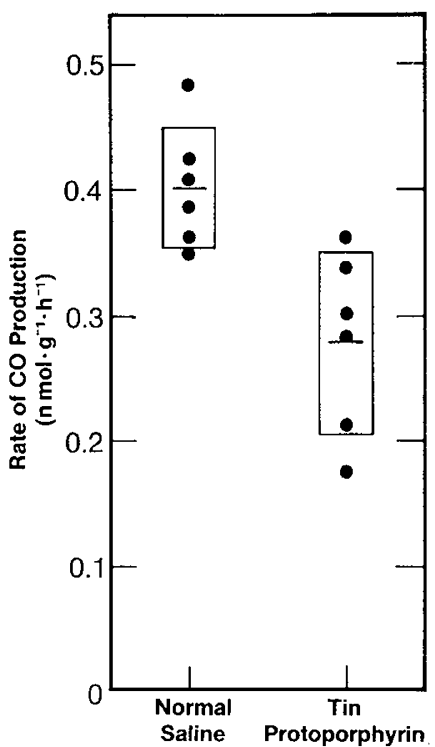

Fig. 1. Calculated rates of $\mathrm{CO}$ production for mice treated with tin protoporphyrin or normal saline. $p<0.01$. Rectangles indicate mean \pm $1 \mathrm{SD}$.

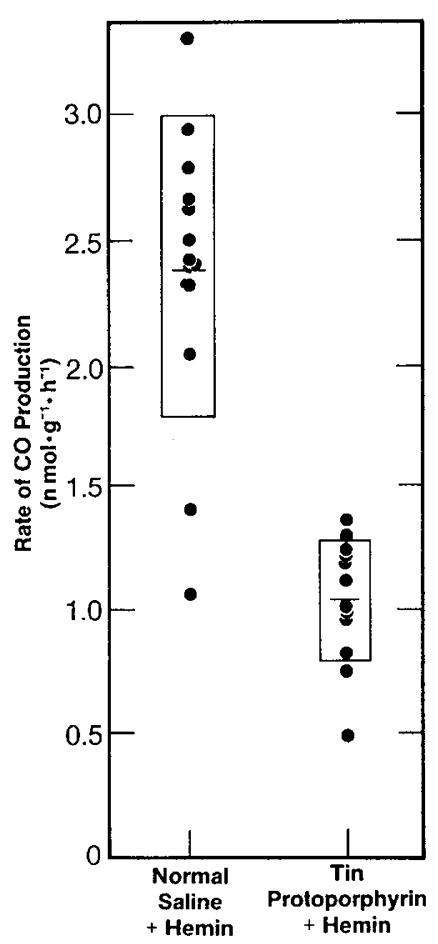

Fig. 2. Calculated rates of $\mathrm{CO}$ production for hemin-injected mice given tin protoporphyrin versus normal saline. $p<0.0001$. Rectangles indicate mean $\pm 1 \mathrm{SD}$. 
production is a quantitative measure of heme catabolism. While several assumptions concerning body stores of $\mathrm{CO}$ were necessary to calculate production rates, the validity of these assumptions is supported by the calculated rate of $\mathrm{CO}$ production for salinetreated animals of $0.40 \mathrm{nmol} \cdot \mathrm{g}^{-1} \cdot \mathrm{h}^{-1}$, a value close to the predicted rate of $0.48 \mathrm{nmol} \cdot \mathrm{g}^{-1} \cdot \mathrm{h}^{-1}$.

In mature mice, we found a $30 \%$ decrease in $\mathrm{CO}$ production after treatment with tin protoporphyrin. This result indicates that tin protoporphyrin decreases heme breakdown in adult animals with normal rates of heme catabolism. In addition, the reduced $\mathrm{CO}$ production confirms that tin protoporphyrin reduces serum bilirubin levels by inhibition of heme oxygenase rather than by inhibition of biliverdin reductase activity, decreased bilirubin binding by albumin, or accelerated bilirubin clearance by the liver (11).

Tin protoporphyrin also inhibited heme breakdown when mice were given a hemin burden approximately 10 times their normal daily heme turnover. In this situation, tin protoporphyrin decreased the rate of $\mathrm{CO}$ production by about $50 \%$ compared to saline-injected animals, but did not completely prevent a rise in $\mathrm{CO}$ production after hemin injection. This finding is similar to that of Sassa et al. (16), who found that tin protoporphyrin decreased, but did not normalize serum bilirubin levels in mice with severe hemolytic anemia. The greater percent inhibition of $\mathrm{CO}$ production following hemin administration as compared to the basal state is what would be expected in the in vivo situation if heme levels were normally well below the saturating levels of the enzyme. Partial inhibition of the enzyme would cause the heme levels to rise to a concentration which results in an increased rate of formation of the product $(\mathrm{CO})$. In contrast, in the hemin loaded state when the enzyme is functioning at near saturation levels, further increases in heme concentration will not increase the rate of $\mathrm{CO}$ formation.

In contrast to the present report on adult mice, Cowan et al. (4) found that tin protoporphyrin injections did not affect the $\mathrm{CO}$ production of newborn rats. Both their experimental design and their biological model differed from ours in several respects that could conceal heme oxygenase inhibition by tin protoporphyrin. The rat pups were studied $24 \mathrm{~h}$ after receiving $25 \mathrm{nmol} /$ $\mathrm{g}$ of tin protoporphyrin, whereas the mice received $50 \mathrm{nmol} / \mathrm{g}$ with a repeat dose just before the $\mathrm{CO}$ sampling period started. The disparity in tin protoporphyrin dose is even greater when allowance is made for the several-fold decrease in hepatic heme oxygenase activity that occurs during the first postnatal month in rats $(8,18)$, and the gradual decrease in hepatic weight relative to total body weight during infancy. In 7-day-old rats, the effect of tin protoporphyrin on serum bilirubin concentration has been shown to be dose dependent (8). The rat pups were allowed to suckle before the determination of $\mathrm{CO}$ exhalation. We eliminated milk feedings $18 \mathrm{~h}$ before the study because milk appeared to produce a spurious increase in $\mathrm{CO}$ production, which probably did not result from heme catabolism. The rat pups were fasted during the $\mathrm{CO}$ production study while adult mice had access to a sugar water solution. Since a fast of $3 \mathrm{~h}$ can increase hepatic heme oxygenase activity in newborn rats (18), this could further obscure inhibition of the enzyme by tin protoporphyrin. The attempt by Posselt et al. (14) to elicit a latent inhibition of heme oxygenase $100 \mathrm{~h}$ after giving tin protoporphyrin by relying on the gradual release of heme $55 \mathrm{~h}$ after forming a hematoma is probably less apt to succeed than the intraperitoneal injection of a bolus of hemin just before the $\mathrm{CO}$ collection period. The disparate results for newborn rats as opposed to adult mice suggest that under steady-state conditions, tin protoporphyrin will only reduce $\mathrm{CO}$ and bilirubin production when heme oxygenase activity is inhibited sufficiently to result in alternative routes for eliminating heme $(1,2,8)$.

Acknowledgments. The authors thank Cynthia Fetzer for her technical assistance, Dr. Samuel Schwartz for his advice, and Amy Wilkes for her secretarial assistance.

\section{REFERENCES}

1. Bissell DM, Guzeliau PS 1980 Degradation of endogenous hepatic heme by pathways not yielding carbon monoxide. J Clin Invest $65: 1135$

2. Cantoni L, Gibbs AH, DeMatteis F 1981 Loss of haem and haemoproteins during generation of superoxide anion and hydrogen peroxide: a pathway not involving production of carbon monoxide. Int $\mathrm{J}$ Biochem 13:823

3. Coburn RF 1970 Endogenous carbon monoxide production. N Engl J Med 282:207

4. Cowan BE, Kwong LK, Vreman HJ, Stevenson DK 1983 The effect of tin protoporphyrin on the bilirubin production rate in newborn rats. Pediatr Pharm 3:95

5. Douglas CG, Haldane JS, Haldane JBS 1912 The laws of combination of hemoglobin with carbon monoxide and oxygen. J Physiol 44:275

6. Drummond GS, Kappas A 1981 Prevention of neonatal hyperbilirubinemia by tin protoporphyrin IX, a potent competitive inhibitor of heme oxidation. Proc Natl Acad Sci USA 78:6466

7. Drummond GS, Kappas A 1982 Chemoprevention of neonatal jaundice potency of tin protoporphyrin in an animal model. Science 217:1250

8. Drummond GS, Kappas A 1984 An experimental model of postnatal jaundice in the suckling rat: suppression of induced hyperbilirubinemia by Sn-protoporphyrin. J Clin Invest 74:142

9. Eckman JR, Modier S, Eaton JW, Berger E, Engel RR 1977 Host heme catabolism in drug-sensitive and drug-resistant malaria. J Lab Clin Med 90:767

10. Engel RR 1977 Alternative sources of carbon monoxide. In: Berk PD, Berlin NI (eds) Chemistry and Physiology of Bile Pigments. National Institutes of Health, Bethesda, pp 148-155

11. Kappas A, Drummond GS, Simionatto CS, Anderson KE 1984 Control of heme oxygenase and plasma levels of bilirubin by a synthetic heme analogue, tin-protoporphyrin. Hepatology 4:336

12. Luomanmaki K, Coburn RF 1969 Effects of metabolism and distribution of carbon monoxide on blood and body stores. Am J Physiol 217:354

13. Morrison PR 1948 Oxygen consumption in several mammals under basal conditions. J Cell Comp Physiol 31:281

14. Posselt AM, Ochikubo CG, Vreman HJ, Stevenson DK 1984 The effect of tinprotoporphyrin on bilirubin production in newborn rats after hematoma formation. Pediatr Res 18:350A

15. Russell ES, Bernstein SE 1966 Blood and blood formation. In: Green EL (ed) Biology of the Laboratory Mouse. McGraw-Hill, New York, pp 351-372

16. Sassa S, Drummond GS, Bernstein SE, Kappas A 1983 Tin protoporphyrin suppression of hyperbilirubinemia in mutant mice with severe hemolytic anemia. Blood 61:1011

17. Tenhunen R 1977 Microsomal oxygenase. In: Berk PD, Berlin NI (eds) Chemistry and Physiology of Bile Pigments. National Institutes of Health, Bethesda, pp 19-25

18. Thaler MM, Gemes DL, Bakken AF 1972 Enzymatic conversion of heme to bilirubin in normal and starved fetuses and newborn rats. Pediatr Res 6:197 